\title{
BISHOP'S MOVE
}

\author{
JON WYNNE - TYSON
}

Fontwell, West Sussex
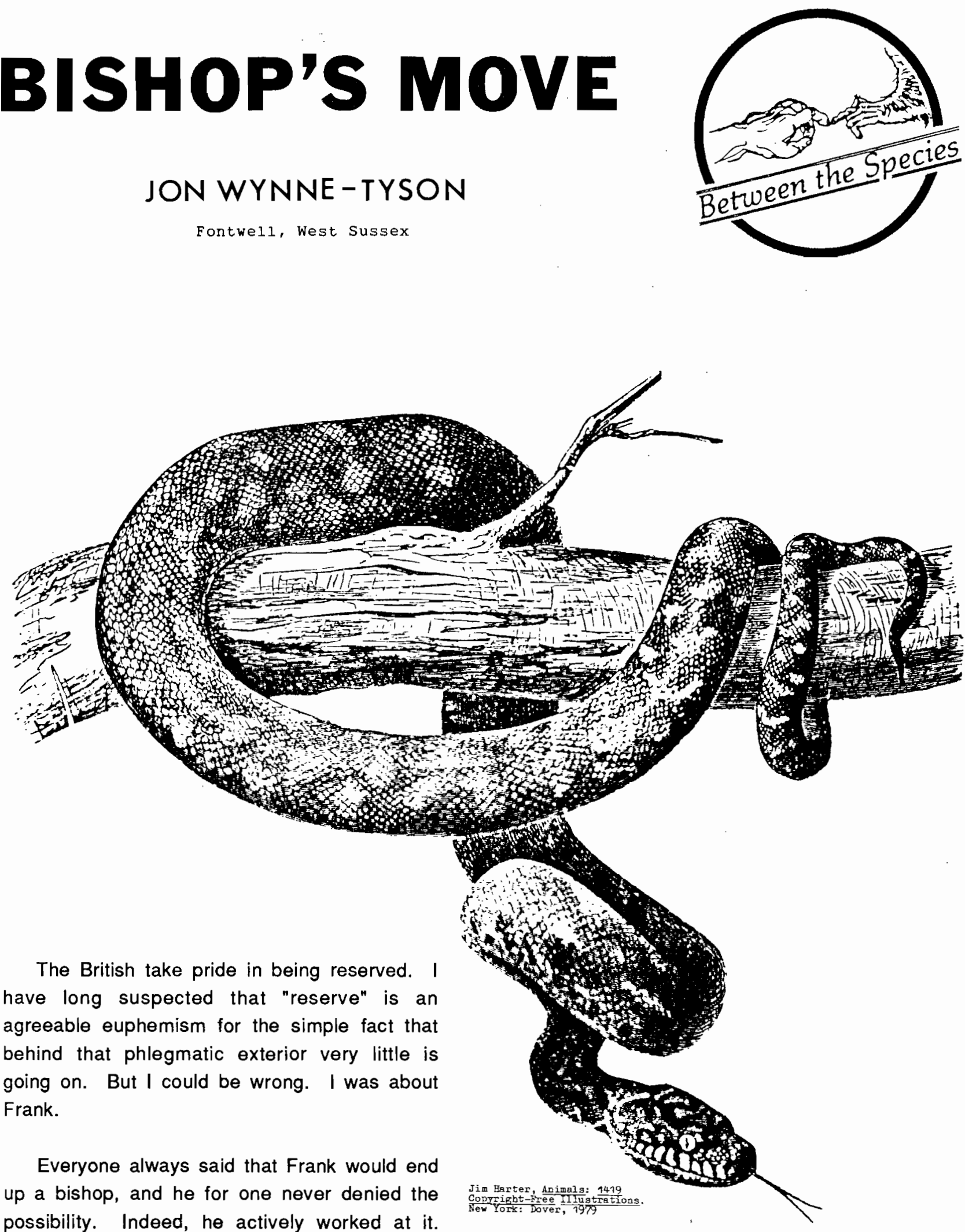

Which meant, of course, that he was a very political animal, for you do not rise through the clerical ranks without knowing what makes the temporal world tick. Politics and idealism are uneasy bedfellows. Jesus Christ would not have made it as a sidesman.

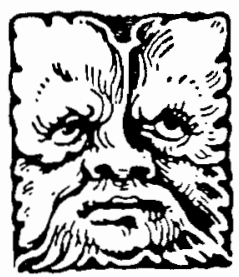

FICTION 
But it was not until we discovered a mutual liking for chess that I knew Frank other than to exchange High Street pleasantries about cricket and the weather. The boredom and predictability of his sermon had long before convinced me that I was an Easter-andChristmas-only churchgoer. His congregation in that charming if not exactly radical part of West Sussex was small but faithful, mostly gentleman farmers, retired army and navy, and the cream of the local gentry. Reserve and containment were what they understood. They knew exactly what to expect of Frank, and they got it every time. For anyone wanting the Tory party at prayer, St. Mark in the Meadow, East Burpham, was tops.

What eventually happened would have astonished me even more had our weekly chess encounters not brought a degree of intimacy he shared with no-one else. With no-one else, that is, but Angela Elfin-Davis, the beautiful doe-eyed, dark-haired daughter of a widely respected and well connected Welsh minister.

She moved into Frank's life and heart a year or two before he made the grade of archdeacon, and he was besotted by her.

"Watch that young man," my wife remarked shortly before she died, "he's going places. That girl knows what she's about."

Sure enough, not all that long after their marriage, Frank's archdeaconry was confirmed, and although to his female parishoners' disappointment the ensuing years did not bless their union with issue, their devotion to each other seemed not one jot diminished.

On an April day of uncertain weather, Frank and I were setting up our pieces for a new game.

"There are whispers," I said, "about a suffragan being appointed before long. I'm white this time, I think."
Frank nodded. "I shall be sorry to leave this parish."

"It's that certain, then?"

"Consecration should be announced any day."

"Congratulations. When do you bang on the door?"

"Bang?"

"Don't new bishops bang on the door on consecration day?"

He had the build of a full back and the features of a film idol, but it was charm and application rather than quickness of mind that had helped him up the ladder.

"Oh, I see. Just after Christmas, I think."

"Angela must be pleased. You'll be an unusually youthful bishop."

"Yes," he said, "I suppose she will be pleased."

"You sound doubtful."

"I think she would have liked to return to Wales. The hills call to her, she says."

"She'll acclimatize."

"Maybe. I'm just hoping there won't be too many lifestyle problems."

"Life. . .? Ah!" I said, "you mean the. .." waved a hand ". . .meat and drink business."

It was no secret that Angela, some years Frank's junior, was a teetotaler by family tradition, and until marriage an active campaigner for animals' rights. Rumour had it that pre-marriage she had carried many a banner in Bristol and points west. That wasn't quite Frank's style, and his concession to 
teetotalism was less than total; but in the matter of walnuts and two vegs he was wholly committed. It had been a sudden conversion to what he called a harmless diet. Until he met Angela he was a perfectly normal flesh-pots man.

"You know how it is with most bishops," he said.

I nodded. "And old Crumpton is no exception."

"We had him to dinner recently, and quite frankly it got a bit sticky."

\section{"You don't mean you offered him Ribena?"}

"Lord, no, he got his wine. Angela had grape juice and he never knew. But she drew the line at giving him meat, so she did a nut roast."

I whistled. "Old Crumpton tucking into a mock duck strains the imagination a little."

"It wasn't shaped like a duck," Frank said defensively." Angela wouldn't go that far. It was just a perfectly honest nut roast."

"And delicious they can be," I said stoutly. "I remember the one you gave me very well. The chestnuts and pineapple slices round the edge were particularly good."

"It wasn't the roast itself so much as the ensuing theology that was a trifle worrying," Frank said, countering my knight to king's bishop three with queen to rook five.

I took his pawn. "A bit of bible bashing over the coffee, you mean?"

He grimaced. "That kind of thing."

"I know animals' rights are all the rage," I said, "but churchmen have never had much to say about non-humans' place in the scheme of things."

He rose and paced the carpet.

"Quite. And, frankly, these last couple of years with Angela have opened my eyes a bit. Her angle is that we can hardly expect better treatment from each other until we stop exploiting the weaker species. It makes such absolute sense."

"You're in love," I said. "It always makes things seem clearer. Some things, anyway."

"You probably won't believe it," he said, "but for a year or more now there have been times when I have looked at my congregation and wondered if I was right to let them off the hook a moment longer."

"I'm not sure I'm 'with you," | said. "I daresay you'll be wanting to take my pawn next."

"Very well." $\mathrm{He}$ stopped and made his move before continuing his pacing. "What I mean is, I get sudden urges to let 'em have it good and strong."

"Good Lord!" I said. "I'd never have thought it."

"If you turned up more often, you might have noticed signs of tension."

"I was there the other day. You seemed pretty. . .normal."

"Well, I can tell you, I get very churned up inside at times."

"Anyway," I said, "I take it you haven't actually. . .let them have it?"

He had forgotten about the chess. He stopped his pacing and began to warm his bottom at the log fire. May still seemed a long way off, yet it was a clammy day with a threal of thunder in the air. I moved my bishop 
to knight three without any real hope of a response, though pawn to rook five was strongly indicated.

"Just wait until the New Year," he said.

\section{"Why the Now Year?"}

"I'll be a bishop by then."

"And able to let your hair down?"

"Why not? l'll be as far up the tree as I'm likely or really want to get."

II can't think of many archbishops with dietetic hang-ups, I grant you. Pig farming and good cellars seem more their line."

"It's not only that. Angela is very wrapped up in the Glastonbury Circle."

This was new to me.

"Sounds rather druidical, if that's the word."

"It's more on psychic lines. I can't say I go along with it myself."

"It'd be pushing the boat out a bit far," I agreed.

"Psychic, you say. You mean, spiritualism? There is a certain mysterious other-worldliness about her."

"Not spiritualism exactly. More a belief in malign and benign influences; predestination; occult pressures."

"Doesn't sound terribly Crumpton," I agreed.

"I feel I'm chancing my arm enough as it is without getting into that kind of thing."

"You're not feeling cooler about the animals' rights issue?"

BEIWEEN THE SPECIES
"Definitely not. I'd go to the stake over that. Angela is the most tender-hearted and lovely girl in the world and I have not had a moment's doubt for years. It was just a bit of a struggle at the beginning when I smelled bacon."

"I'd keep a low profile over the occult business, though."

"I intend to."

The storm had crept up with little warning. There was a tremendous clap of thunder simultaneously with a flash of lightning that filled the room. In the silence that followed, the fire crackled and spat, seemingly before the downpour to come, but perhaps due to an advance raindrop down the wide straight chimney.

"That was a big one," I said. "Well, it's your move."

He left the fire and sat down again.

"I say," he said, "look at that."

I leaned forward. Immediately above the board I could smell the very faintest trace of burning. On my king's rook five square was a small scorched imprint of a crucifix, less than an inch long.

"It must have been an ember," I said.

"But where is it? The ember?"

"Burned itself out, I suppose."

"Odd."

"Very odd. Your move, then."

Except for Remembrance Sunday I didn't go to church again until Christmas, but I continued to play chess with Frank and had no reason to 
suppose from his conversation and bearing, or from local rumour, that he had done anything to blot his copybook before the congregation of St. Mark in the Meadow.

His consecration had been duly announced in the spring. He didn't mention the subject when we played chess, but I knew from friends in the village that he and Angela's dinner invitations had been more frequent since news of his appointment. I wondered, idly, how they were making out over the meat question, but it wasn't until our last game before Christmas that the subject came up.

"We've been using this TVP stuff," he said.

"TVP? Sounds like an antiseptic."

"Textured vegetable proteins. Meat analogues."

"Imitation meat?"

I had heard of the stuff. My older girl had gone through a West Country commune phase before settling for her barrister in Parsons Green.

"You can do a lot with it. Almost anything, in fact, that you do with the real thing. But curries and chilli con carne are the best. Indistinguishable."

"Well, yes," I said, "you get this ethnic kind of food wherever you go these days. Even the Chetwynde-Stroodes were dishing out great dollops of rather murky rice the other day. Because it's cheaper, I suppose. But what about Christmas? Don't tell me they do convincing TVP turkeys."

We'll be having Christmas at home, so the problem won't arise."

I smiled. "You'll get by until you make the bishopric, then, and after that you can stop pussy-footing?"

"You make me sound rather calculating."
I shrugged. "I'm not judging. It's a rough world and we all have to look ahead a bit to survive."

"I'm getting some stick from Angela."

"Because you're ambitious?"

"She doesn't seem to grasp, bless her, that spiritual ambition hinges on the logistics of the material variety. No rank, no power."

"A good old army truism," I agreed.

"And she's more into this Glastonbury thing than ever. She damned. . .very nearly brought it up when we had Portsmouth and Winchester to dinner recently."

"My God!" I said. "And on top of almond rissoles and grapefruit juice!"

He didn't see it as a subject for levity.

"She's a dear, wonderful, marvelous girl, and her whole attitude to non-human species is totally commendable, but I will confess that when she gets started on malign influences 1 get a little warm under the collar."

"Never mind," I said, "it is very good for a bishop's wife to have some sense of good and evil. I think that's check."

I should have got to the church earlier. It was bitterly cold and I had supposed the turnout would not be large. I couldn't have been more wrong. What with the season and the fact that it would be Frank's last sermon before going on to higher things, the place was packed. I had to be content with a pew too near the door for comfort but with a good side-on view of most of the congregation. Frank was almost invisible behind a Saxon pillar.

I saw almost all the locals and several craggy faces that were unfamiliar. One of 
these was sitting nest to old Crumpton, and they seemed to be exchanging notes. I could guess why they were there and that Frank must be feeling nervous.

But his voice rang strong and confident, and when he began his sermon I could tell it was going to be business as usual. Maybe it was my rapidly freezing feet, but his deep drone seemed slower and more episcopal than ever, and his sermon was so packed with platitudes and undemanding exhortations that the forthcoming ceremony of consecration struck me as a quite unnecessary endorsement of the obvious. To all intents and purposes Frank was a fully fledged bishop of the old school, totally in control of his congregation, expecting nothing of them but their presence and fiscal contribution, a predictable link with all they needed or wanted to know of a higher power.

Half suspecting incipient hypothermia, for my legs were dead to the groin, I was beginning to doze off when there was a deafening noise and a blinding flash which it took some moments to recognize as the arrival of a thunder storm. It was followed by an absolute silence, doubtless because the congregation were half stunned by an explosion that could have been in the church itself. Even Frank stopped speaking, and no doubt his ear drums were ringing as loudly as mine. Then, as his audience began to shuffle and whisper, some rattling their fingers in their ears to restore normal hearing, he resumed his address. But now his voice was louder, more urgent, less slow.

"Oh, but why," he demanded, his tone challenging and almost derisive, "why do I stand before you in the role of suppliant, asking your respect for virtues you have no desire or intention to observe; exhorting you to obey rules that you consciously and determinedly break every day of your life; pleading that you show a compassion and a kinship that is totally foreign to your coarsened and unrepentant natures? Why do we not admit that the devil's time has come? That all of you here---yes, every man, woman and child---have long since sold your souls to the powers of evil, for all that you have sanctified your thoughtless actions by loyalty to habit and tradition. Christmas! The season of good cheer and goodwill. The time we remember gentle Jesus meek and mild and are full only of loving kindness toward our relatives and neighbours. Rubbish and balderdash! Christmas! The time of gluttony and calculated giving. Of booze, plethora and boredom. Of mindless idleness or cruel, pointless blood-sports over the cold fields, the values of Jesus as far removed from your all too human and self-centred minds as the fate of those harmless birds and beasts whose bodies are even now sizzling in your timecontrolled ovens. Shall I tell you who should be sitting in your pews? All the weak and timid creatures who, at your tables and for your shallow pleasures, you have eaten, beaten, chased and tortured in the three hundred and sixty five sanguinary days since we last celebrated this gruesome moment in the year's calendar. I wish I could restore each and every one of them to life and assure them that the kingdom of God has indeed come and henceforth they need never again fear the cruel hearts and hands of Homo sapiens, the creator of pain and suffering, the greatest bully this unhappy world has ever known."

He drew breath.

"But the birds and beasts are not before me, are they? No, only row upon row of popeyed human faces, all in a state of hypnotic fascination at the sight of an archdeacon who has obviously gone clean off his rocker. And you will return home, all of you: Colonel Barker and his lady, both as resolute in the hunting field as in their brain-washing of gullible young men recruited to slaughter our politicians' chosen enemies; Sir Ruper Redpill of drug company fame, and Mr. Peter Facecoat the cosmetic tycoon, in whose laboratories countless defenseless animals have been tortured over the past year to make another (continued p. 159) 
(continued from p. 152)

brand-name acceptable to a public already surfeited in alternatives; Mr. Mark Slittingham, our distinguished farmer and landowner, whose batteried pigs and chickens have brought ugly, stinking Belsens with full planning approval to so many green fields. ..

I rose quietly and left. It was all too painful. I walked slowly home through the empty village to my cottage and put fresh logs on the smouldering fire. I looked gloomily at the chess table, remembering our many games. It is so difficult to find agreeable company of precisely one's own standard.

\section{SOCIETY POR THE STUDY} OF ETHICS AND ANIMALS

CALL E EOR PAPERS

$$
\text { for }
$$

Pacific Division Meeting in conjunction with the meetings of the American Philosophical Association

San Francisco or Berkeley March, 1989

Papers on any topic impacting ethical issues concerning non-human animals are welcome. Pósible topics include:

The moral (in)significance of being natural (as opposed to domesticated or genetically engineered)

Are Animal Liberation Front activities consonant with an animal rights ethic?

Historical studies of conceptions of the moral standing of animals.

Papers must be double-spaced and be ten to fifteen pages in length. Those interested in submitting papers should make their intention, along with an indication of the projected topic, known as soon as that is possible. Final papers, or substantive drafts, must be received by September 15, 1988 . to:

send statements of intent and papers

Prof. Steve F. Sapontzis Department of Philosophy California state University Hayward, California 94542.

Those interested in chairing the session or in being commentators should contact Prof. Sapontzis by September 15 .

(Paper(s) and comments will be published in Between the Species.)
Frank and Angela's Christmas card had fallen from the mantlepiece and was lying in the hearth. I picked it up and put it with the others. As I did so I noticed that the card bore a crucifix, but the ordinary kind that doubles so oddly for the kiss of love or death---and it had just about obliterated Frank's name. Presumably the card had fallen on some hot ash.

Presumably.

\section{BOOKS RECEIVED}

Ursula K. Le Guin

Buffalo Gals And Other Animal Presences

Santa Barbara: Capra Press, 1987

$196 \mathrm{p}$

$\$ 15.95$ hardback

Virginia C. Holmgren

The Way of the Hummingbird

In Legend, History, and

Today's Gardens

Santa Barbara: Capra Press, 1986

$167 p$, bibliography, index

$\$ 8.95$ paper

Harriet Ritvo

The Animal Estate

The English and Other Crea-

tures In the Victorian Age

Cambridge: Harvard University

Press, 1987

$288 \mathrm{p}$, notes, illustration

credits, index

$\$ 25.00$ hardback

John Vrvyan

In Pity and In Anger

A Study of The Use of Animals In Science

Marblehead, MA: Micah Publications, 1988

$164 \mathrm{p}$, index

$\$ 9.95$ paper

Peter S. Wenz

Environmental Justice

Albany: State University of

New York Press, 1988

$343 p$, notes, index

$\$$ 